Supporting information

for

\title{
Photochemically Induced Autocatalysis in the Chlorate Ion-Iodine System
}

\author{
Mónika Galajda, Gábor Lente, István Fábián* \\ Department of Inorganic and Analytical Chemistry, University of Debrecen, P.O.B. 21 H-4010 \\ Derecen, Hungary
}

\section{Experimental section}

Materials. All chemicals used in this study $\left(\mathrm{NaClO}_{3}, \mathrm{I}_{2}, \mathrm{HClO}_{4}\right)$ were of the highest purity available from commercial sources. Doubly deionized and ultrafiltered water from a Millipore Q system was used to prepare the stock solutions and samples.

Instrumentation. Quantitative kinetic measurements on the photochemical reaction were performed in a HP-8543 diode-array instrument using the method and general operating procedures described in earlier publications (see references 11-13). A built-in Hewlett-Packard 89090A Peltier thermostat was used to maintain constant temperature $\left(25.0 \pm 0.1^{\circ} \mathrm{C}\right)$. The solutions were kept homogeneous during the photochemical experiments using the built-in magnetic stirrer of the standard cell compartment of the HP-8543 instrument. A 3-mm stirring rod was used inside standard quartz cuvettes (optical path length: $1.000 \mathrm{~cm})$. The geometry of the setup was carefully tested and it was made sure that the stirring rod never disrupted the light beam. The light source was calibrated by both ferrioxalate actinometry and reproducing observations on the known photoreaction of 2,6-dichloro-1,4-benzoquinone (see reference 11). All results were reproducible within $5 \%$.

A Perkin Elmer Lambda 2S scanning spectrophotometer was used in control experiments to study the process with the lowest light intensity possible. An external circulating bath was used to maintain constant temperature in this case. Kinetic traces similar to the ones detected in the diode-array instrument were also observed in this conventional double-beam spectrophotometer, but with rather lengthy induction periods. When freshly prepared solutions were used, the induction period varied from two hours to more than a day depending primarily on how much ambient light the sample was exposed to before placing it in the cell compartment of the spectrophotometer. If solutions were not prepared freshly (a day old or older), the induction periods became shorter. 


\section{Discussion of reactions 1-5}

Reaction 1:

$$
\begin{array}{r}
\mathrm{I}_{2}+\mathrm{ClO}_{3}{ }^{-}+\mathrm{H}_{2} \mathrm{O}+h v \rightarrow \mathrm{IO}_{3}{ }^{-}+\mathrm{H}_{2} \mathrm{OI}^{+}+\mathrm{Cl}^{-} \\
v_{1}=\alpha_{1 \mathrm{a}}\left[\mathrm{I}_{2}\right]\left[\mathrm{ClO}_{3}^{-}\right]\left[\mathrm{H}^{+}\right]+\alpha_{1 \mathrm{~b}}\left[\mathrm{I}_{2}\right]\left[\mathrm{ClO}_{3}{ }^{-}\right]
\end{array}
$$

A possible sequence of elementary steps which interpret the rate equation:

$$
\begin{aligned}
& \mathrm{I}_{2}+h v \rightarrow 2 \mathrm{I} \\
& v_{1.1}=\Phi_{1.1} N_{V} \\
& \mathrm{I}+\mathrm{I}^{\circ} \rightarrow \mathrm{I}_{2} \\
& v_{1.2}=k_{1.2}\left[\mathrm{I}^{\prime}\right]^{2} \\
& \mathrm{I}^{*}+\mathrm{ClO}_{3}{ }^{-} \rightarrow \mathrm{IClO}_{3}{ }^{-} \\
& v_{1.3}=k_{1.3}\left[\mathrm{I}^{*}\right]\left[\mathrm{ClO}_{3}^{-}\right] \\
& \mathrm{IClO}_{3}{ }^{-\cdot} \rightarrow \mathrm{I}^{-}+\mathrm{ClO}_{3}{ }^{-} \\
& v_{1.4}=k_{1.4}\left[\mathrm{IClO}_{3}^{-{ }^{-}}\right] \\
& \mathrm{IClO}_{3}{ }^{-\cdot} \rightarrow \mathrm{OI}^{-}+\mathrm{ClO}_{2} \\
& v_{1.5}=k_{1.5}\left[\mathrm{IClO}_{3}^{-{ }^{-}}\right] \\
& \mathrm{IClO}_{3}{ }^{-\cdot}+\mathrm{H}^{+} \rightarrow \mathrm{HOI}+\mathrm{ClO}_{2} \\
& v_{1.6}=k_{1.6}\left[\mathrm{IClO}_{3}^{\left.-{ }^{-}\right]}\right]\left[\mathrm{H}^{+}\right] \\
& 0=\Phi_{1.1} N_{V}+k_{1.4}\left[\mathrm{IClO}_{3}^{-{ }^{-}}\right]_{\mathrm{ss}}-k_{1.2}\left[\mathrm{I}^{{ }^{\prime}}\right]_{\mathrm{ss}}{ }^{2}-k_{1.3}\left[\mathrm{I}^{\circ}\right]_{\mathrm{ss}}\left[\mathrm{ClO}_{3}{ }^{-}\right] \\
& 0=k_{1.3}\left[\mathrm{I}^{*}\right]_{\mathrm{ss}}\left[\mathrm{ClO}_{3}{ }^{-}\right]-k_{1.4}\left[\mathrm{IClO}_{3}{ }^{-\cdot}\right]_{\mathrm{ss}}-k_{1.5}\left[\mathrm{IClO}_{3}{ }^{-}\right]_{\mathrm{ss}}-k_{1.6}\left[\mathrm{IClO}_{3}{ }^{-\cdot}\right]_{\mathrm{ss}}\left[\mathrm{H}^{+}\right]
\end{aligned}
$$

$N_{\mathrm{V}}$ is the absorbed photon count for iodine (see eq. E9 for definition and reference 11 for further details), $\Phi_{1.1}$ is the quantum efficiency. Steady-state assumption for reactive intermediates I and $\mathrm{IClO}_{3}{ }^{-}$ gives:

The overall rate of reaction 1 can be given using the steady-state concentrations:

$$
v_{1}=k_{1.5}\left[\mathrm{IClO}_{3}^{-{ }^{-}}\right]_{\mathrm{ss}}+k_{1.6}\left[\mathrm{IClO}_{3}^{-{ }^{-}}\right]_{\mathrm{ss}}\left[\mathrm{H}^{+}\right]
$$

Rearrangement of eq. E2 gives:

$$
\left[\mathrm{IClO}_{3}^{-{ }^{-}}\right]_{\mathrm{ss}}=k_{1.3}\left[\mathrm{I}_{\mathrm{ss}}\left[\mathrm{ClO}_{3}^{-}\right] /\left(k_{1.4}+k_{1.5}+k_{1.6}\left[\mathrm{H}^{+}\right]\right)\right.
$$

Assuming that $k_{1.4}>k_{1.5}+k_{1.6}\left[\mathrm{H}^{+}\right]$(i.e. $\mathrm{IClO}_{3}{ }^{-\cdot}$ forms in an unfavorable equilibrium and dissociates rapidly compared to its redox reactions) simplifies eq. E4:

$$
\left[\mathrm{IClO}_{3}{ }^{-{ }^{-}}\right]_{\mathrm{ss}}=k_{1.3}\left[\mathrm{I}^{\mathrm{I}}\right]_{\mathrm{ss}}\left[\mathrm{ClO}_{3}{ }^{-}\right] / k_{1.4}
$$

Substituting eq. E5 into eq. E1:

$$
0=\Phi_{1.1} N_{V}+k_{1.4} k_{1.3}[\mathrm{I}]_{\mathrm{ss}}\left[\mathrm{ClO}_{3}{ }^{-}\right] / k_{1.4}-k_{1.2}\left[\mathrm{I}_{\mathrm{ss}}{ }^{2}-k_{1.3}\left[\mathrm{I}_{\mathrm{ss}}\left[\mathrm{ClO}_{3}^{-}\right]=\Phi_{1.1} N_{V}-k_{1.2}\left[\mathrm{I}_{\mathrm{ss}}{ }^{2}\right.\right.\right.
$$

Form eq. E6, the following formula follows:

$$
[\mathrm{I}]_{\mathrm{ss}}=\left(\Phi_{1.1} N_{V} / k_{1.2}\right)^{0.5}
$$

Substituting eqs. E7 and E5 into eq. E3 gives

$$
v_{1}=\left(k_{1.5} k_{1.3}\left[\mathrm{ClO}_{3}^{-}\right] / k_{1.4}+k_{1.6} k_{1.3}\left[\mathrm{ClO}_{3}^{-}\right]\left[\mathrm{H}^{+}\right] / k_{1.4}\right)\left(\Phi_{1.1} N_{V} / k_{1.2}\right)^{0.5}
$$

The definition of $N_{\mathrm{V}}$ is: 


$$
N_{V}=\text { Const } \times \sum_{\text {all } \lambda}\left[\frac{\left[\mathrm{I}_{2}\right] \times \varepsilon_{\mathrm{I}_{2}}}{\sum_{\text {all species }} c_{\mathrm{i}} \times \varepsilon_{\mathrm{i}}} \times \lambda \times E_{L}(\lambda) \times\left(1-10^{-A(\lambda)}\right]\right.
$$

In eq. E9, Const is a constant specific for the instrument, $\varepsilon_{\mathrm{i}}$ values are molar absorbances of various species, $c_{\mathrm{i}}$ values are the concentrations, $E_{L}(\lambda)$ is the energy emitted by the lamp at wavelength $\lambda, A(\lambda)$ is the absorbance of the solution at wavelength $\lambda$. Under the conditions used in our study (especially low $\mathrm{I}_{2}$ concentrations), $N_{V}^{0.5}$ can be reasonably approximated by $\zeta\left[\mathrm{I}_{2}\right]$, where $\zeta$ is a constant independent of $\left[\mathrm{I}_{2}\right]$.

$$
N_{V}^{0.5} \approx \zeta\left[\mathrm{I}_{2}\right]
$$

Substituting eq. E10 into eq. E8 gives:

$v_{1}=\left(k_{1.5} k_{1.3}\left[\mathrm{ClO}_{3}^{-}\right] / k_{1.4}+k_{1.6} k_{1.3}\left[\mathrm{ClO}_{3}^{-}\right] / k_{1.4}\left[\mathrm{H}^{+}\right]\right) \zeta\left[\mathrm{I}_{2}\right]\left(\Phi_{1.1} / k_{1.2}\right)^{0.5}$

Eq. E11 is the same as rate equation (1) with composite parameters $\alpha_{1 \mathrm{a}}=k_{1.6} k_{1.3} / k_{1.4} \zeta\left(\Phi_{1.1} / k_{1.2}\right)^{0.5}$ and $\alpha_{1 \mathrm{~b}}=k_{1.5} k_{1.3} / k_{1.4} \zeta\left(\Phi_{1.1} / k_{1.2}\right)^{0.5}$.

\section{Reaction 2:}

$$
\begin{aligned}
& \mathrm{HOCl}+\mathrm{H}^{+}+\mathrm{Cl}^{-} \rightleftharpoons \mathrm{Cl}_{2}+\mathrm{H}_{2} \mathrm{O} \\
& K_{2}=\left[\mathrm{Cl}_{2}\right] /\left([\mathrm{HOCl}]\left[\mathrm{Cl}^{-}\right]\left[\mathrm{H}^{+}\right]\right)
\end{aligned}
$$

This is a well established and widely studied equilibrium step. The kinetics is known, the reaction is fast enough to be considered as an equilibrium in our study (reference 4).

\section{Reaction 3:}

$$
\begin{gathered}
\mathrm{H}_{2} \mathrm{OI}^{+}+\mathrm{ClO}_{3}{ }^{-} \rightarrow \mathrm{IO}_{3}{ }^{-}+\mathrm{HOCl}+\mathrm{H}^{+} \\
v_{3}=k_{3}\left[\mathrm{H}_{2} \mathrm{OI}^{+}\right]\left[\mathrm{ClO}_{3}^{-}\right] /\left[\mathrm{H}^{+}\right]
\end{gathered}
$$

alternative form:

$$
v_{3}=\left(k_{3} / K\right)[\mathrm{HOI}]\left[\mathrm{ClO}_{3}{ }^{-}\right] \text {where } K=\left[\mathrm{H}_{2} \mathrm{OI}^{+}\right]\left[\mathrm{H}^{+}\right] /[\mathrm{HOI}](\sim 0.03 \mathrm{M})
$$

This is a direct reaction between $\mathrm{HOI}$ and $\mathrm{ClO}_{3}{ }^{-}$followed by fast reactions between oxyiodine and oxychlorine species (reference 4$)$. At the $\mathrm{pH}$ of this study $(<0.8)$, HOI is predominantly protonated to give $\mathrm{H}_{2} \mathrm{OI}^{+}$( $\mathrm{p} K \sim 1.5$, reference 4 ). Therefore, rate equation (3) can be written using the concentrations of major species.

\section{Reaction 4:}

$$
\begin{gathered}
\mathrm{H}_{2} \mathrm{OI}^{+}+2 \mathrm{HOCl} \rightarrow \mathrm{IO}_{3}^{-}+2 \mathrm{Cl}^{-}+4 \mathrm{H}^{+} \\
v_{4}=k_{4}\left[\mathrm{H}_{2} \mathrm{OI}^{+}\right][\mathrm{HOCl}]
\end{gathered}
$$

A direct reaction between $\mathrm{H}_{2} \mathrm{OI}^{+}$and $\mathrm{ClO}_{3}{ }^{-}$followed by fast reactions between oxyiodine and oxychlorine species (reference 4).

\section{Reaction 5:}

$$
\begin{gathered}
\mathrm{I}_{2}+\mathrm{Cl}_{2}+2 \mathrm{H}_{2} \mathrm{O} \rightarrow 2 \mathrm{H}_{2} \mathrm{OI}^{+}+2 \mathrm{Cl}^{-} \\
v_{5}=k_{5}\left[\mathrm{I}_{2}\right]\left[\mathrm{Cl}_{2}\right]
\end{gathered}
$$

This is a well known process (reference 4). 


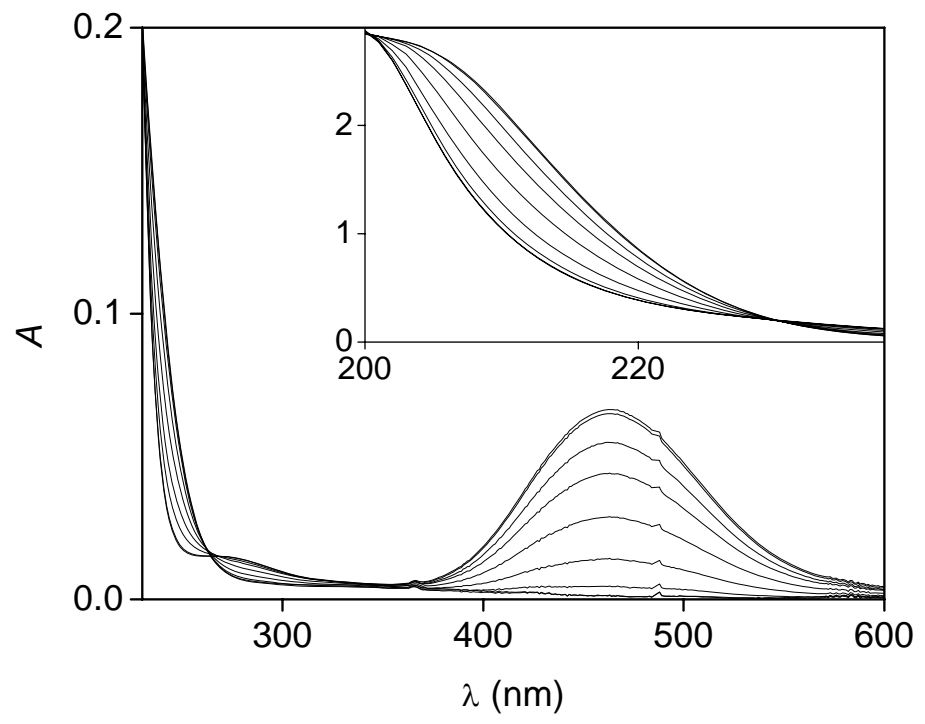

Figure S1. UV-vis spectra recorded in the photoinitiated reaction of $\mathrm{I}_{2}$ with $\mathrm{ClO}_{3}{ }^{-}$. Reaction times: 2, 23, 53, 63, 73, 83, 93, 103 and 188 s. $\left[\mathrm{ClO}_{3}{ }^{-}\right]=25.1 \mathrm{mM} ;\left[\mathrm{I}_{2}\right]=88 \mu \mathrm{M} ;\left[\mathrm{H}^{+}\right]=0.948 \mathrm{M}$; continuous illumination; $\mathrm{T}=25.0^{\circ} \mathrm{C}$. Note the lack of considerable absorbance at $360 \mathrm{~nm}$ which confirms that $\mathrm{I}_{3}{ }^{-}$ is not formed in the reaction.

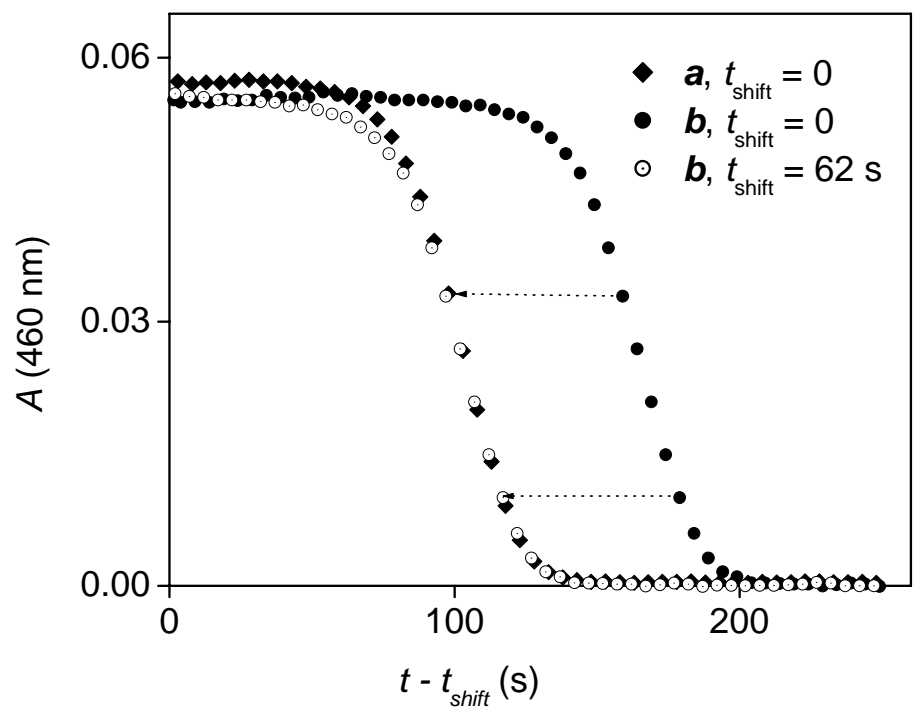

Figure S2. Kinetic curves in the photoinitiated reaction of of $\mathrm{I}_{2}$ with $\mathrm{ClO}_{3}{ }^{-}$. $\left[\mathrm{ClO}_{3}{ }^{-}\right]=25.1 \mathrm{mM}$; $\left[\mathrm{I}_{2}\right]=$ $80 \mu \mathrm{M} ;\left[\mathrm{H}^{+}\right]=0.948 \mathrm{M} ; \boldsymbol{a}$ : continuous illumination, $\boldsymbol{b}$ : interrupted illumination $(20 \%) ; \mathrm{T}=25.0^{\circ} \mathrm{C}$. 


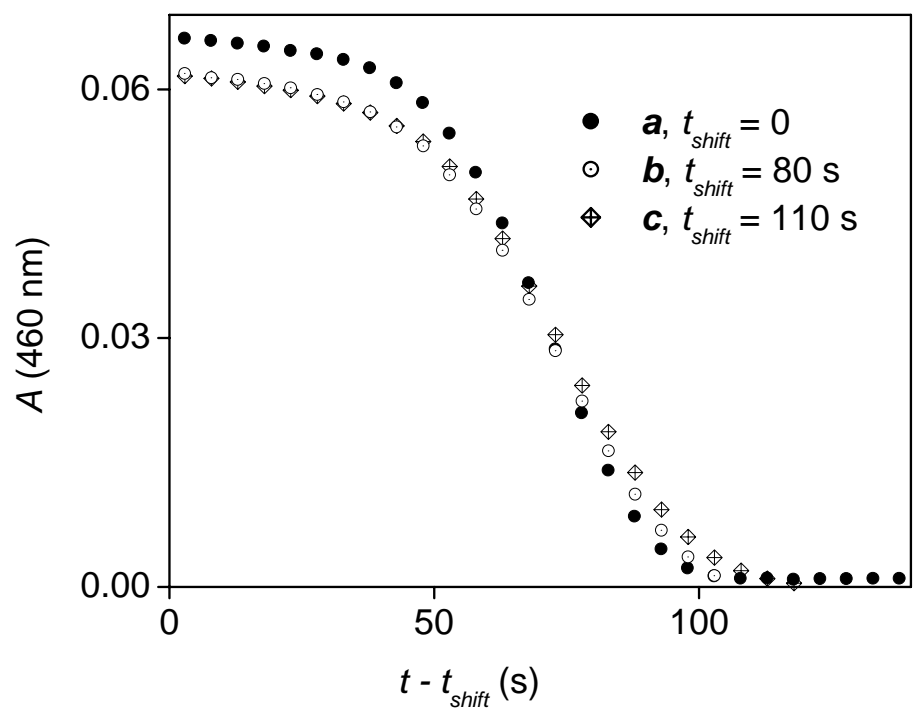

Figure S3. Shifted kinetic curves as a function of acidity in the photoinitiated reaction of of $\mathrm{I}_{2}$ with $\mathrm{ClO}_{3}{ }^{-} \cdot\left[\mathrm{ClO}_{3}{ }^{-}\right]=25.1 \mathrm{mM} ;\left[\mathrm{I}_{2}\right]=88 \mu \mathrm{M} ;\left[\mathrm{H}^{+}\right]=0.948 \mathrm{M}(\boldsymbol{a}), 0.356 \mathrm{M}(\boldsymbol{b}), 0.237 \mathrm{M}(\boldsymbol{c})$; continuous illumination; $\mathrm{T}=25.0^{\circ} \mathrm{C}$.

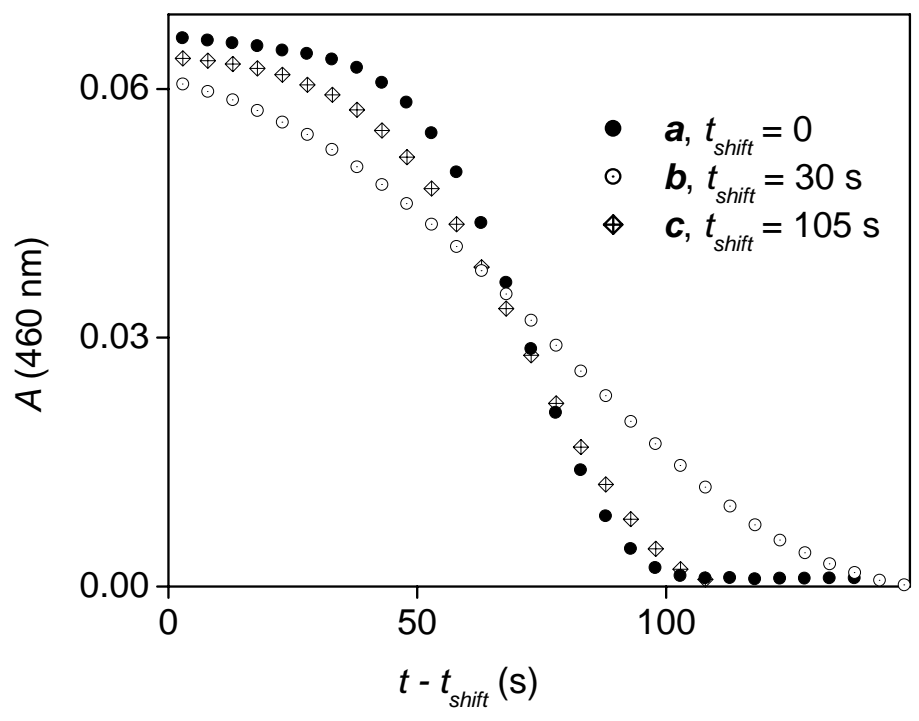

Figure S4. Shifted kinetic curves as a function of $\mathrm{ClO}_{3}{ }^{-}$concentration in the photoinitiated reaction of of $\mathrm{I}_{2}$ with $\mathrm{ClO}_{3}{ }^{-} .\left[\mathrm{ClO}_{3}{ }^{-}\right]=25.1 \mathrm{mM}(\boldsymbol{a}), 16.7 \mathrm{mM}(\boldsymbol{b}), 8.3 \mathrm{mM}(\boldsymbol{c}) ;\left[\mathrm{I}_{2}\right]=88 \mu \mathrm{M} ;\left[\mathrm{H}^{+}\right]=0.948 \mathrm{M}$; continuous illumination; $\mathrm{T}=25.0^{\circ} \mathrm{C}$. 


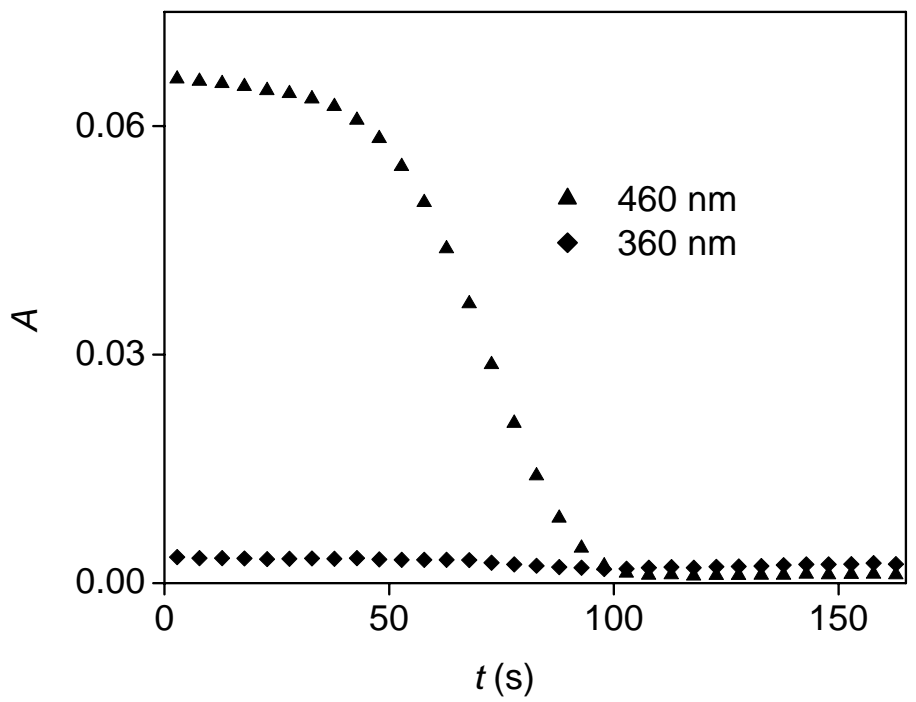

Figure S5. Kinetic curves measured at two wavelengths in the photoinitiated reaction of $\mathrm{I}_{2}$ with $\mathrm{ClO}_{3}{ }^{-}$. $\left[\mathrm{ClO}_{3}{ }^{-}\right]=25.1 \mathrm{mM} ;\left[\mathrm{I}_{2}\right]=88 \mu \mathrm{M} ;\left[\mathrm{ClO}_{3}{ }^{-}\right]=0.948 \mathrm{M}$; continuous illumination; $\mathrm{T}=25.0^{\circ} \mathrm{C}$.

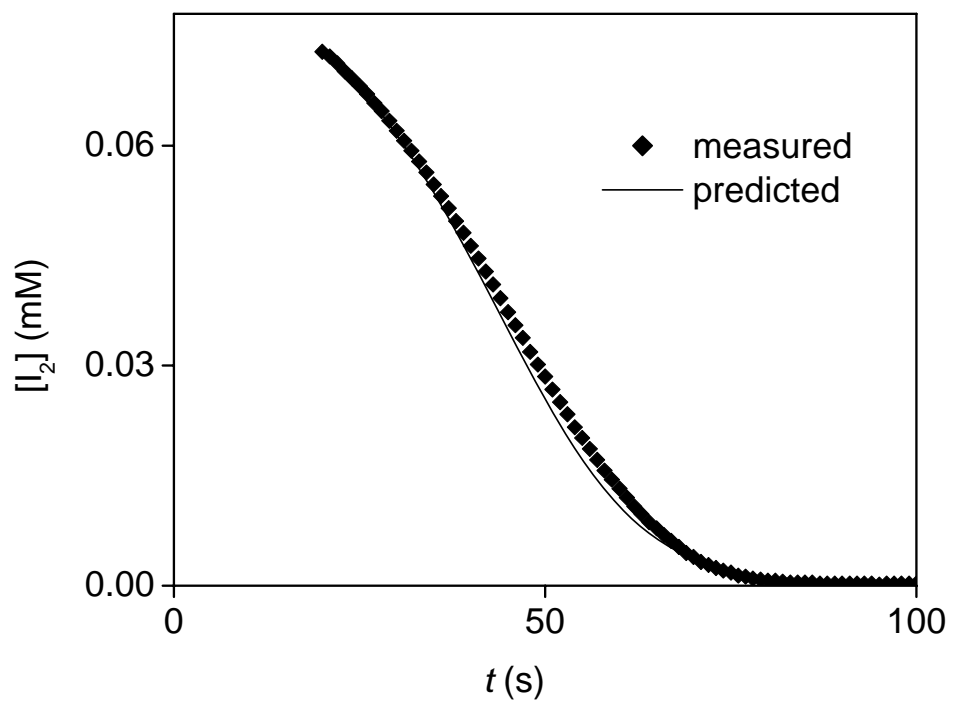

Figure S6. Measured (markers) and predicted (line) kinetic curves in the $\mathrm{ClO}_{3}{ }^{-}-\mathrm{I}_{2}$ system by a conventional scanning spectrophotometer after mid-course addition of $\mathrm{HOCl}(9 \mu \mathrm{M}) . \quad\left[\mathrm{ClO}_{3}{ }^{-}\right]=25.1$ $\mathrm{mM} ;\left[\mathrm{I}_{2}\right]=83 \mu \mathrm{M} ;\left[\mathrm{H}^{+}\right]=0.948 \mathrm{M} ; T=25.0^{\circ} \mathrm{C}$. 


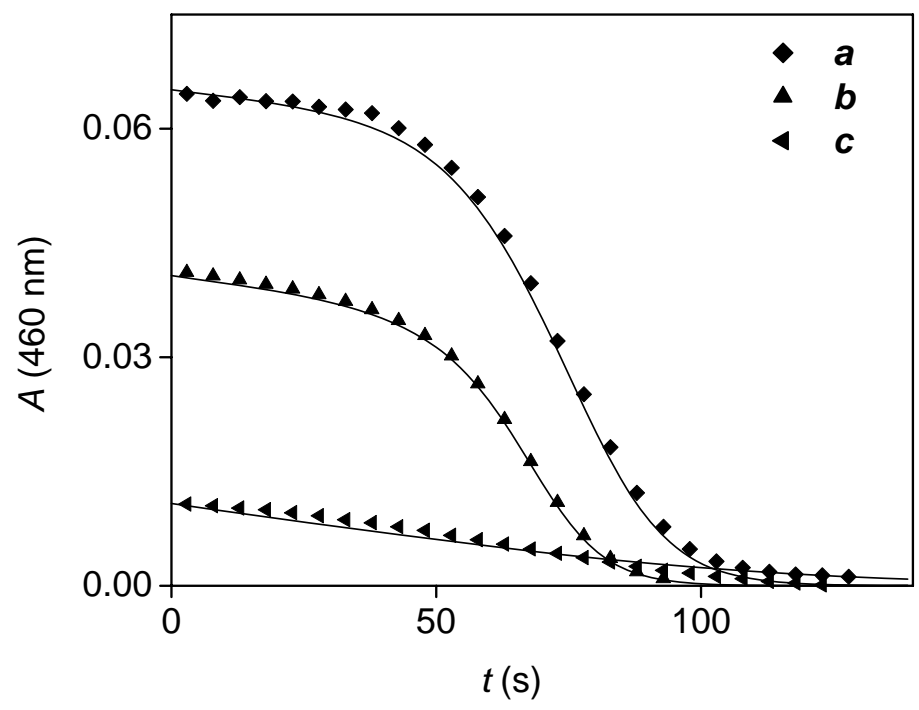

Figure S7. Measured (markers) and fitted (lines) kinetic curves in the photoinitiated reaction of $\mathrm{I}_{2}$ with $\mathrm{ClO}_{3}{ }^{-}$. $\left[\mathrm{I}_{2}\right]=88 \mu \mathrm{M}(\boldsymbol{a}), 58 \mu \mathrm{M}(\boldsymbol{b}), 21 \mu \mathrm{M}(\boldsymbol{c}) ;\left[\mathrm{ClO}_{3}^{-}\right]=25.1 \mathrm{mM} ;\left[\mathrm{H}^{+}\right]=0.948 \mathrm{M}$; continuous illumination; $T=25.0^{\circ} \mathrm{C}$.

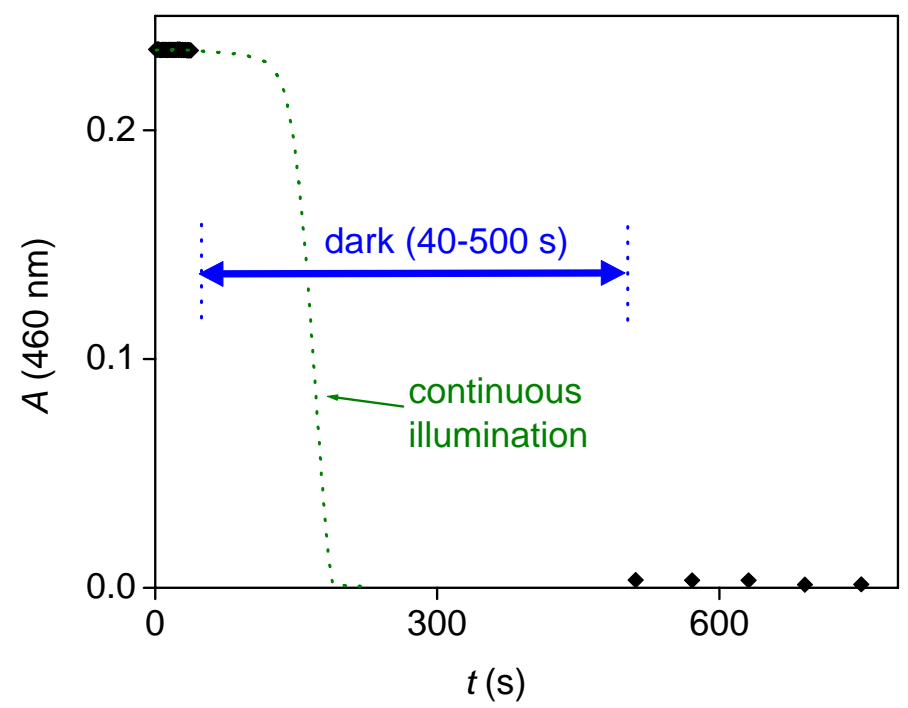

Figure S8. Kinetic curve measured in the photoinitiated reaction of $\mathrm{I}_{2}$ with $\mathrm{ClO}_{3}{ }^{-}$. A long dark period was inserted into the measurement to prove the fact that no light is necessary to maintain the reaction in the rapidly decreasing region. $\left[\mathrm{I}_{2}\right]=0.39 \mathrm{mM} ;\left[\mathrm{ClO}_{3}{ }^{-}\right]=25 \mathrm{mM} ;\left[\mathrm{H}^{+}\right]=0.948 \mathrm{M} ; T=25.0^{\circ} \mathrm{C}$. 


\section{Stoichiometric considerations:}

The most likely overall stoichiometry is

$$
3 \mathrm{I}_{2}+5 \mathrm{ClO}_{3}^{-}+3 \mathrm{H}_{2} \mathrm{O} \rightarrow 6 \mathrm{IO}_{3}^{-}+5 \mathrm{Cl}^{-}+6 \mathrm{H}^{+}
$$

Considerations supporting this stoichiometry:

1. Our experiments with ion chromatography identified $\mathrm{IO}_{3}^{-}$and $\mathrm{Cl}^{-}$only as major products. Qunatification of $\mathrm{Cl}^{-}$was hindered by the fact the background electrolyte $\left(1 \mathrm{M} \mathrm{HClO}_{4}\right)$ also contains small amount of $\mathrm{Cl}^{-}$as an impurity.

2. $\mathrm{HOCl}$ is not a possible final product because it would be mainly transformed to $\mathrm{Cl}_{2}$ in the presence of $\mathrm{Cl}^{-}$through an equilibrium $\left(\mathrm{HOCl}+\mathrm{H}^{+}+\mathrm{Cl}^{-} \rightleftharpoons \mathrm{Cl}_{2}+\mathrm{H}_{2} \mathrm{O}\right)$ at the $\mathrm{pH}$ of this study.

3. $\mathrm{HClO}_{2}$ is not a possible final product because it decomposes in acidic medium and the decomposition product $\mathrm{ClO}_{2}$ has a very characteristic UV-vis spectrum, which was never detected in this study.

4. $\mathrm{Cl}_{2}$ has a molar absorption of $69.7 \mathrm{M}^{-1} \mathrm{~cm}^{-1}$ at $325 \mathrm{~nm}$ (Cooper, J. N; Margerum, D. W. Inorg. Chem. 2003, 32, 5905). In the experiment shown in Figure S8 $\left(\left[\mathrm{I}_{2}\right]_{0}=0.39 \mathrm{mM} ;\left[\mathrm{ClO}_{3}^{-}\right]_{0}=25 \mathrm{mM} ;\left[\mathrm{H}^{+}\right]=\right.$ $0.948 \mathrm{M}$ ), the final absorbance reading at $325 \mathrm{~nm}$ was smaller than 0.001. taking the conservative estimate that the absorbance contribution of $\mathrm{Cl}_{2}$ cannot be larger than 0.002 at this wavelength, the upper limit for $\mathrm{Cl}_{2}$ concentration in the final mixture is $0.029 \mathrm{mM}$, which means that less than $7 \%$ of the chlorine-containing products may be $\mathrm{Cl}_{2}$.

5. Kinetic information about chlorine-containing species (Lengyel, I.; Li, J.; Kustin, K.; Epstein, I. R. J. Am. Chem. Soc. 1996, 118, 3708) showed that $\mathrm{Cl}_{2}$ is the one that reacts fastest with $\mathrm{I}_{2}$. The formation of large amounts of $\mathrm{Cl}_{2}$ in a system where $\mathrm{I}_{2}$ is a reactant would therefore be kinetically unfeasible.

6. In the related photoreaction between $\mathrm{ClO}_{2}$ and $\mathrm{I}_{2}$ (Rábai, G.; Kovács, K. M. J. Phys. Chem. A 2001, $105,6167)$, the dominating product was also $\mathrm{Cl}^{-}$. 